\title{
Article
}

\section{Forgotten Plotlanders: Learning from the survival of lost informal housing in the UK.}

Bower, Richard

Available at http://clok.uclan.ac.uk/14689/

Bower, Richard (2016) Forgotten Plotlanders: Learning from the survival of lost informal housing in the UK. Housing, Theory and Society, 34 (1). pp. 79105. ISSN 1403-6096

It is advisable to refer to the publisher's version if you intend to cite from the work. http://dx.doi.org/10.1080/14036096.2016.1197850

For more information about UCLan's research in this area go to http://www.uclan.ac.uk/researchgroups/ and search for <name of research Group>.

For information about Research generally at UCLan please go to http://www.uclan.ac.uk/research/

All outputs in CLoK are protected by Intellectual Property Rights law, including Copyright law. Copyright, IPR and Moral Rights for the works on this site are retained by the individual authors and/or other copyright owners. Terms and conditions for use of this material are defined in the policies page.

\section{CLoK}

Central Lancashire online Knowledge www.clok.uclan.ac.uk

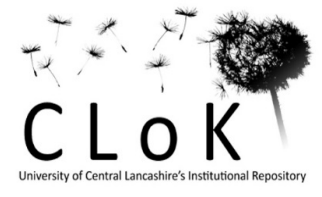




\title{
Forgotten Plotlanders:
}

\section{Learning from the survival of lost informal housing in the UK.}

\begin{abstract}
:
Colin Ward's discourses on the arcadian landscape of 'plotlander' housing are unique documentations of the anarchistic birth, life, and death of the last informal housing communities in the UK. Today the forgotten history of 'plotlander' housing documented by Ward can be re-read in the context of both the apparently never-ending 'housing crisis' in the UK, and the increasing awareness of the potential value of learning from comparable informal housing from the Global South. This papers observations of a previously unknown and forgotten plotlander site offers a chance to begin a new conversation regarding the positive potential of informal and alternative housing models in the UK and wider Westernised world.
\end{abstract}

\section{Keywords:}

informal space, housing, Colin Ward, plotlanders, anarchism.

\section{Word count:}

8662, excluding endnotes, references, etc

12657, including endnotes, references, etc 


\section{Forgotten Plotlanders:}

\section{Learning from the survival of lost housing anarchy in the UK.}

If seeking to engage with ideas of alternative housing models in the UK architectural practitioners and academics alike confront the negative economic, political, and sociocultural assumptions that pervade informal, anarchist, and even self-build housing. In both the Global North and Global South respectively, the formality of housing can be perceived as acting as a 'yardstick' with which to measure the development of countries towards the formalised conventions of Westernised space. Thus informal space and housing has become almost extinct as a potential model of development outside of the economic absence (and concurrent productive scarcity and social participation) of Global South contexts.

The remaining historical examples of informal housing in the UK have been largely swallowed up by the seemingly inevitable spread of conventional formal housing. Buoyed by the last 30 years of neoliberal economic policy and systemic developer housing models (Brenner and Theodore 2002; Rolnik 2013), a lost landscape of plotlander housing examples dotted along the South-East UK coastline have been demolished, redeveloped, or simply forgotten. The social, economic, and political failure of these lost and forgotten communities has been assumed confirmed by the 'successful' demolition, co-option, and formalisation of the best examples, or by the deprivation found in notorious places like Jaywick Sands (Newnham 2000).

In this context, Colin Ward and Dennis Hardy's discourse Plotlanders (1972) remains a classic study of the last widespread anarchist housing movement in the UK, documenting the informal seaside housing that began at Pagham Beach, Selsey in Sussex. For Ward and Hardy this community of informal seaside homebuilders is 
exemplary of the critical moment in social history which defined the plotlander movement, and the subsequent inexorable advance of institutionalised planning models that were used as a means to 'tidy up' unwanted informal encroachments along the coastlines of Kent, Essex, and Sussex. ${ }^{1}$ Yet it is remarkable how little this debate has been explored in contemporary discourse, particularly in the context of both the apparently never-ending 'housing crisis' in the UK (Pallister 2015), and the increasing awareness of the potential value of learning from comparable informal housing ${ }^{2}$ from the Global South ${ }^{3}$ (Parnell and Oldfield 2014; McGuirk 2014; Bower 2016; P. M. Ward 2008). Thus, the opportunity to unearth and study a forgotten plotlander site offers a chance to begin a new conversation regarding the positive potential of informal and alternative housing models in the Westernised world.

This paper explores the historical origins of the plotlander movement as a foundation from which to re-read Colin Ward's studies in the context of wider discourse concerning informal housing as a global condition. The paper begins with a contextualisation of the intersections of anarchist theory, informal space as a global condition, and the historic emergence and disappearance of plotlander movement in the UK. This theoretical context frames the critical documentation and analysis of newly discovered plotlander housing development on the North Kent coastline known as Studd Hill. This previously unknown example of successful informal architecture in the UK subsequently offers a critical lens with which to discuss the ability of informal architecture to confront the prevailing neoliberal housing models in the UK today. Thus, the paper concludes by suggesting that key spatial characteristics that define Studd Hill suggest a platform from which to re-consider the value of informal housing in the UK. This trajectory of analysis begins to re-imagine the social production of informal space (Shields 1999, 183) as an opportunity to confront, contest, and disrupt the seemingly unending housing crisis in the UK.

\section{Anarchism, Global Informality, and 'Plotlanders'}

Colin Ward's extensive documentation of plotlanders and alternative housing landscapes in the UK remains an invaluable study of a social and architectural history that has been almost entirely lost and forgotten. Supported by his extensive work on the positive potential of anarchist theory (1996a; 1999; 2004) Ward remains one of the 
foremost advocates of both alternative housing methodologies in the UK and the social landscapes they produced. His analysis is founded upon the work of a wide range of anarchist political and social theorists that includes Peter Kropotkin (2006), Ivan Illich (1973), Kenneth Boulding (cited in: Benello 1967), Gustav Landauer (Graham 2005), and Martin Buber. In the wake of tectonic movements in political and economic theory emerging from the failures of communist state politics, Ward found himself responding to the anarchist alternative to Marxist theory, notably citing the work of the Russian founder of collectivist anarchism, Mikhail Bakunin:

We want the reconstruction of society and the unification of mankind to be achieved, not from above downwards by any forms of authority, nor by socialist officials, engineers, and other accredited men of learning - but from below upwards, by the free federation of all kinds of workers' associations liberated from the yoke of the State. (Bakunin 1872)

However, instead of a strategy for revolution or an ideological vision of society, Ward's interpretation is grounded in practice and offers a model of anarchism as a theory of organization and social agency. His analysis of principles of self-organisation in relation to housing, schooling, family, self-management, and governance is an attempt to relieve the tension between practicality and ideological aspiration (C. Ward 1996a, 7-9). Thus, Ward came to recognise the importance of proposing a future that could be realised through social agency and action, instead of relinquishing political agency in pursuit of a model of a future utopia built on state revolution.

Writing on plotlanders predominantly in the 1970s, Ward was not alone in exploring alternative housing models for the UK. Indeed this was a short-lived but highly innovative period for participatory housing in the UK, with projects including Walter Segal's self-build council housing in Lewisham, and Nabeel Hamdi's similar attempts to reinvent social housing for the GLC (Greater London Council) using a modified model of John Habraken's 'Supports' (1972) system of housing - the PSSHAK (Primary Support Structures and Housing Assembly Kits) at Adelaide Road (both projects notably in London). However, Ward's focus upon informal housing and the alternative social relationship that defined such development have become almost consigned to history as a footnote or curiosity. 
In the wake of the continued axiomatic split between Marxist and anarchist political theory (Springer 2014; Harvey 2015b), perhaps it should not be of surprise to find that whilst discourse concerning the poltics of urbanisation and the history of socialist housing continues to abound, the notion of an anarchist housing policy remains merely either a historical curiosity or isolated in a geographical intrigue aimed at the effervescent cities of the Global South (P. M. Ward 2008, 284). However, Ward's discourse and critical analysis appears prescient when considered in relation to the social and political relations that define contemporary housing practices in the UK:

When we look at the powerlessness of the individual and the small face-toface group in the world today and ask ourselves why they are powerless, we have to answer not merely that they are weak because of the vast central agglomerations of power in the modern, military-industrial state, but that they are weak because they have surrendered their power to the state. It is as though every individual possessed a certain quantity of power, but that by default, negligence, or thoughtless and unimaginative habit or conditioning, he has allowed someone else to pick it up, rather than use it himself for his own purposes. (C. Ward 1996a, 23)

Ward's documentation of informal housing resonates with his anarchist critique of the emerging capitalist state hegemony he recognised in UK politics. His analysis of the plotlander housing movement in the UK reflects many of the same themes explored in 'Architecture Without Architects' (Rudolfsky 1987), 'Architecture for the Poor' (Fathy 1976), and 'Freedom to Build (Fichter and Turner 1972). Yet whilst the architectural contexts of these books are scattered in the space of 'other' (culturally assumed as 'backward' or 'primitive') cultures, ${ }^{4}$ crucially Ward's discourse is in contrast situated within the core of Western space and society.

In essence, plotlander informal housing was a practical, informal, and unconsciously anarchistic response by the working classes to the emerging intersection of capitalist economics and urbanisation theory (Hardy and Ward 1984, 27). The subsequent sociopolitical model of class gentrification and social formalisation of the working-classes continued apace throughout the twentieth century (Hardy and Ward 1984, 18-21). This is not to decry or overlook the immense challenge faced by planners in the aftermath of 
the Second-World-War (Glynn and Oxborrow 1976), or the necessity to engage with working-class urban slum housing conditions (Malpass 2003). Yet it is in the interwar period that the foundations for an economically isolated urban working-class community to pursue, produce, and grasp upon the last opportunity to build a home for yourself outside of the now pervasive economics of land and home ownership as economic speculation and capitalist social relations:

Even by 1939 only about 18 per cent of working-class families were owneroccupiers (compared with the national figure of 31 per cent (Glynn and Oxborrow 1976)). ... Sandwiched between the two, however - between the artisans of the council estates and the petty bourgeoisie of suburbia - were many others, swayed by the arguments for home ownership yet without the economic means to enter the main race. It was from would-be property owners such as these that many of the plotlanders came to make their own distinctive bid for a house and some land. A little cottage in the Essex plotlands - painstakingly built with materials carried on a bus and bicycle from East London on days off work, and aptly named 'Perserverance' (sic), typifies the immense sacrifice needed to achieve what became almost a mystical objective of acquiring a home of one's own. (Hardy and Ward $1984,18)$

Within these observations certain themes resonate profoundly with the cultural crises of contemporary housing in the UK: the sense of being 'swayed by arguments for home ownership yet without the means to enter the race', and contradictorily, the inability for contemporary 'perseverance' to affect any change to the ability to 'get on the property ladder'. Ward's case studies of informal hosing in the UK might thus offer profound potential for critical self-reflective analysis of the unending housing crisis' of Westernised space.

In apparent contrast to the socialist state sanctioned housing programs of post Second World War modernism, the anarchist informality of plotlanders seems inefficient, inelegant, and individualistic in a way that is wildly counter to contemporary associations of home-ownership and individuality in the form of cultural consumption. Informal space, housing, and social relations seem so dis-connected from contemporary 
life in the UK and Westernised space more generally as to seem incongruous and abstracted from the problems of today's contemporary society, politics, and housing practices. However this perspective is highly skewed by current cultural hegemony surrounding the commodification of housing by capitalist economics and neoliberal ideologies (Harvey 2015a, 15-24). In the wake of the First World War, the UK and wider Europe faced an unprecedented demand for working class housing.

"Previous models of urban housing, based either on the bourgeois apartment block or the standard terraced house, simply did not meet needs in terms of economics, density or the required scale of provision." (Till and Schneider 2005, 15-16)

The collective response of politicians, planners, and architects reinforced the ideological faith in urbanisation that was latent in modernism. The demand for sufficient numbers of dwellings at minimal cost produced a dramatic reduction of the space standards, with legislative regulation shifting design intentions from the quality of spaces to their efficiency, and thus a concurrent intensification of the commodification of housing. This shift in agenda and agency was crucial in producing the ideological formalisation and legislative manipulation of housing and planning theory and policy. Thus, the eradication of informal housing in the UK has come to reflect a spatial condition that is forcefully advocated from apex capitalist States as one of many ways to prescribe that rest of the world must 'catch up to the West' (Massey 2005, 4; Sachs 2010; DeMoss-Norman 2015).

Yet when considered in a newly globalised comparison a number of local and global conditions can be seen to intersect: the inexorable growth of informal housing in the Global South (Davis 2007), the increasing global (and local) socio-economic inequality of modern society (Lummis 2010; Neuwirth 2006; Sennett 2004), and the ever-present 'housing crisis' that the UK (and wider Western world) appears to face (Paris 2009; Gram-Hanssen and Bech-Danielsen 2004). If we perceive these issues as inherently interconnected and interdependent (Massey 2006) the conditions of informality globally and the history of plotlanders in the UK are perhaps increasingly relevant to the social-political context of Western space. Consequently, and as Ward and Hardy note themselves some 40 years ago (1972, 67-68), and amongst others Peter Ward 
reconsidered in relation to contemporary Western space (2008), it is reasonable to question whether we might learn valuable insights by engaging with alternative ways of living, whether it be the history of plotlanders or the informal cities of the Global South.

"The word 'plotlands' is used by town planners as a shorthand description for those areas where, in the first forty years of this century, land was divided into small plots and sold, often in unorthodox ways, to people wanting to build their holiday home, country retreat or would be smallholding. Sometimes they simply squatted and eventually gained title through 'adverse possession', the legal phrase for squatter's rights.” $(C$. Ward and Hardy 1972, 63)

Ward's descriptions of plotlander architecture suggests the potential to draw critical comparisons to the contemporary slum cities that define the vast majority of the urban life in cities of the Global South (Roy 2011; Massey 2011; Dawson and Hayes Edwards 2004). However, whilst question and conceptions of a notional urban commons have emerged in recent years (Harvey 2012, 73; McGuirk 2015), the social, political, and economic contexts of Westernised space are perhaps themselves inexorably intertwined with the cultural inertia of consumptive neoliberal capitalism. In contrast, the architectural language of scarcity, adaption, and innovation that defined plotlander housing closely reflects the social relations of production that defines informal urbanisation across the world (J. F. Turner 1976; Neuwirth 2012).

As with both historic and contemporary informal cities, the emergence of plotlander sites in the UK was defined by clear social and economic factors, namely: cheap land, cheap transport, and access to amenities (J. F. Turner 1976, 68-69; Mann 2003, 111). Yet unlike the global inevitability of unending migration and urbanisation that underpins contemporary socio-spatial discourse (Merrifield 2014; Charnock 2010, 1292; Charnock 2010, 1292), the plotlander movement counter-narrative is defined by a process of ruralisation from London to seaside destinations of escape (C. Ward 1996b, 31-32; Mann 2003, 113). This 'diaspora' away from London and ruralisation of a working-class population resonates with anarchist critiques of urbanisation as a mechanism of capitalist ideology: 
"Urban development is the capitalist definition of space. It is one particular realisation of the technically possible, a $n d$ it excludes all alternatives. Urban studies should be seen - like aesthetics, whose path to complete confusion they are about to follow - as a rather neglected type of penal reform: an epidemiology of the social disease called revolt.

The 'theory' of urban development seeks to enlist the support of its victims, to persuade them that they have really chosen the bureaucratic form of conditioning expressed by modem architecture. To this end, all the emphasis is placed on utility, the better to hide the fact that this architecture's real utility is to control men and the relations between them." (Kotanyi and Vaneigem 1961)

Driven by the inequality of impoverished conditions of city life in London, plotlander culture was defined by a growing working-class desire (fuelled by both economic ideology of home ownership, and the rural utopian ideology of 'social activists' like William Morris ${ }^{5}$ ) to escape the city to an increasingly idealised cultural perception of the freedom and tranquillity offered by a seaside or countryside life: 'a space live off the land and be free. ${ }^{6}$ Yet this escape of the working classes to Ward's 'Arcadian landscapes ' prompted the emergence of a social outcry against the blight on the English landscape:

\footnotetext{
"But there is an irony in the fact that the simple life and the rural weekend also attracted the liberal intelligentsia who were the backbone of the preservation lobby ... [who] deplored the way in which 'the adventurous bungalow plants its foundation - a pink asbestos roof screaming its challenge - across a whole parish from the pleasant upland that it has lightheartedly defaced.", (C. Ward and Hardy 1972, 64)
}

As ward himself notes, in retrospect it is easy to recognise this social outcry as nothing more than traditional misanthropy. ${ }^{7}$ Yet this critique of "The wrong sort of people getting a place in the sun" (C. Ward and Hardy 1972, 57) reflects the same social divisions produced by the inexorable rise of informal housing in twentieth century Lima, Peru, and the 'Desborde popular y crisis del Estado' - the 'Popular overflow and crisis of the State' (Matos 1984) where “...new practices were altering the 
conventional social, political, economic and cultural 'rules of the game" (FernándezMaldonado 2007, 5).

These comparative social reactions to the political potential of informal space in both Global North and Global South reveals the possibility that the anarchist socio-spatial relations that defined plotlander history can be critically re-read against the global condition of contemporary informal housing. Yet whilst in the Global South the slow intergenerational development and upgrading of informal housing forms a key part of the urban space, and is driven by social enterprise and necessity (Aravena and Lacobelli 2012; Wakely and Riley 2011), in the UK plotlander sites have suffered from sustained socio-political isolation, leading to either demolition, fragmentation, or at best gentrification to economic extremes of irony. Ward's Selsey case study is exemplary of this formalisation and gentrification (perhaps even Marxist reification) of informal spaces, with houses built out of converted trains now largely used as highly priced and prized holiday or second homes.

The 'visual and social blight on the English landscape' that alternative and informal housing generated is seemingly somewhat integrated with cultural assumptions of anarchism as negative and dangerous to society (C. Ward 1996a, 7-8). Yet these assumptions seem to shift or dissolve when spaces are transformed, co-opted, and commoditised into socially acceptable visions of escapism, and cast off their origins as material expressions of a grassroots contestation of socio-spatial inequality that plotlander housing inherently represented.

As a counter-narrative to the unending process of alienation, commodification, reification, and gentrification in Western space, Ward's discourse is founded upon anarchist principles that he uses to validate and advocate the positive potential of allowing/expecting/empowering (and trusting?) people to look after themselves (Harris 1999). Yet whilst anarchist spatial practices such as these are traditionally critiqued as antithetical to Marxist principles (Burgess 1978; Burgess 1982; Burgess 1977), the positive potential of informal space in Latin and South America were touched upon briefly, yet memorably, in Henri Lefebvre's spatial appropriations of Marxist theory (Shields 1999, 84). Thus we arrive at a potentially valuable intersection of Marxist and anarchist sensibilities in the unlikely example of plotlanders and potentially informal 
spaces more broadly (Bower 2015; 2016). Forgotten places like Studd Hill provide an opportunity to question the contemporary assumptions of Westernised neoliberal housing policies by intersecting anarchist and Marxist spatial theories within a comparison to the informal housing of the Global South.

Marxist and socialist critics of informal housing reduce the political potential of anarchist social relations to mere self-help and thus neoliberal abandonment of state responsibility (Burgess 1982). Yet this narrow and economically ideological misappropriation of the principles of self-help housing is itself a misleading coagulation and reduction of complicated social ideas into political rhetoric. If the spatial and social relations of informal settlements are simply the logical response to intrinsic contradictions of capitalism represented at a global scale in all its inequalities, then the premise of user-choice and autonomy in housing can be read as re-valuing of these spaces as positive global articulations of social difference and transgression that might be re-appropriated as active political contestations. The value of grounding such complex arguments in the practical reality of Studd Hill is not to merely document the social and housing history of a previously lost example of plotlander housing, but to seek to learn from it and question whether key aspects of Ward's 'Arcadia for All' (1984) may still offer vital clues for an informal housing revolution in the UK today (C. Ward 1985)

\section{Studd Hill}

The location of Studd Hill (and plotlander landscapes more generally) is crucial. The north Kent coast has historically prospered and grown as a product of the success of London and the paradoxical need of its citizens to seek refuge from the challenges of city life. Located in between the two contrasting towns of Herne Bay and Whitstable, Studd Hill is somewhat of a cypher for both stories - working class, yet offering the cultural attraction of an alternative, honest, and humble social identity that can (or at least could) be cheaply bought.

To the east of Studd Hill, Herne Bay is the quintessential Victorian seaside town ${ }^{8}-\mathrm{a}$ smaller version of the much better known Margate. Today both Margate and Herne Bay suffer from the same identity crisis: former working class holiday/retirement 
destinations that are not capable of simply adopting the contemporary cultural regeneration model of gentrification by means of art galleries ${ }^{9}$ and delicatessens (Paton 2014, 4-8). ${ }^{10}$

In contrast, to the west of Studd Hill is Whitstable: a small fishing village famous for its local oysters, yet never historically known as being spatially interconnected with the urban diaspora of London. However, since the 1990s it has organically acquired (and subsequently actively adopted) the increasingly facile/cliché Western gentrification process of 'cultural regeneration' (Bianchini 1994, 119-213). Now identified both locally and nationally (i.e. London) as as an artistic and cultural town, Whitstable is buoyed by commuters and second home owners from the capital, each paradoxically seeking the same 'better life by the seaside' in ironic mimicry of Studd Hill's original plotlanders.

Yet in stark contrast to the emergence, spontaneity, and grassroots participation of the original escapees this new lifestyle exists as a commodity and package deal that can (for the right price) be bought and consumed (Gram-Hanssen and Bech-Danielsen 2004). In the context of the history of plotlanders and our example at Studd Hill the irony of the situation is easy to comprehend: history is in many ways repeating itself, but this time as an inversion or paradox of the original humble working-class Londoner escaping to the seaside, with now the extreme wealth of London raising the house prices some to darkly comical levels (Paris 2009, 296-298). ${ }^{11}$

Buoyed by the success of Whitstable and the entrenched comfortable retirement lifestyle bubble of peripheral Herne Bay, today local house prices in areas surrounding Studd Hill continue to rise inexorably. The influence of London housing bubble economics has influenced the value of land and houses around Studd Hill to such an extent that buyers are increasingly willing to 'overlook' the long held cultural and spatial marginalisation of Studd Hill that has previously both isolated and paradoxically protected the remaining plotlander community spirit. ${ }^{12}$

Much of the land that formed the original Studds Hill Farm was lost in 1879 to sea erosion. This land was never reclaimed and it was not till the completion of a substantial sea wall in 1959 that the coastline would be formally 'protected' by the conventions of post-war concrete sea walls. Notably, this protection from the sea was achieved decades 
after the original Studd Hill development had already lost many plotlander homes to erosion themselves, ${ }^{13}$ and by this time the inherent vulnerability of the area was engrained on local memory.

From the early 1920s onwards a Mr Stedman, a soon to be notorious plotland developer, ${ }^{14}$ purchased various stretches of recently devalued and vulnerable agricultural land in sites along the Kent and Essex coastlines. One of these sites was Studds Hill Farm in North Kent, near to the Victorian seaside town of Herne Bay. He soon advertised first 80 and then later a further 40 housing plots for sale in London daily papers, with prices from from $£ 50$ a plot - which included a wooden chalet building! $!^{15}$

Plotlander sites like Studd Hill were in essence a modified form of 'sites and services' development, a model more commonly recognised in peripheral informal city developments of the Global South (J. F. Turner 1983, 208; J. F. Turner 1986, 12). In contrast to earlier and more classically anarchic and organically emergent plotland developments like that at Selsey, Stedman does appear to have submitted some form of plans to the local council, but this was principally linked to the development of sewers (services) that were built in 1933-34, ${ }^{16}$ and (like many plotlander sites) was submitted well after the original settlers had built many informal homes. As with informal housing across the Global South, over the following years water and electricity supplies were slowly connected to the site, whilst Stedman remained the owner and administrator of the remaining plots of land and roads.

The 1932 and subsequent 1947 'Town and Country Planning Act' ${ }^{17}$ had dramatic impacts on Studd Hil and informal housing as an idea in the UK, as plotlanders across the south coast of England became targets for demolision and social isolation. In the immediate postwar period the plotland origins of the site were further eroded when the weight of an increasingly formalised planning structure in the UK began to bear upon informal spaces, beginning with the development of highways agency approved roads that soon surrounded the estate. Of course this bought new street-lighting and improved services, but also formally marked a physical demarcation of a rogue island of informality. This strange demarcation of otherness as a condition of not having council 
owned and maintained roads became a key symbol of the political and social isolation of Studd Hill community that continues to this day.

Thus as Herne Bay continued to grow in the post Second-World-War boom years, Studd Hill remained a leftover space of difference and individuality within an ever increasingly formal sea of surrounding housing development. In spite, or perhaps because of this isolation, Studd Hill conformed to the long-term socio-economic processes observed by Ward and Hardy (C. Ward and Hardy 1972, 64). It is dominated by an architectural language which could be colloquially described as reflecting a shabby chic aesthetic; a style which emerged in Studd Hill from necessity and individuality rather than fashion, and yet has become a keenly commoditised in Western culture. ${ }^{18}$ In most cases the original chalet bungalows were developed by generations of families, incrementally improving and enlarging to the point where now it is at times difficult to see the original chalet skeletons beneath the rich variety of extensions and over-cladding on show.

Yet this richness, variety, and pluralism of invention is a quality that exists at Studd Hill because the informal plotland origins of the site survived in isolation as spatial and social relationships within the community. For decades Studd Hill remained isolated by its identity of informality, unconventionality, and for just generally being different. In essence, local people to this day are still unsure of what to make of Studd Hill: what it was, how it began, and why it is so different. ${ }^{19}$ Any specific justifications of this bias seemingly relate to the somewhat indefinable 'difference' that Studd Hill embodies. This is commonly considered to be represented by the un-adopted roads and general unconventional nature of the people and buildings. Crucially these issues are always subsequently connected to the impact this has traditionally had on the economic value of its housing. Colloquially, if you moved to Herne Bay and asked locals where to buy a house the traditional response would be that most places were fine, but don't buy at Studd Hill. Why? Because it is different.

Today however, increasingly (and worryingly from a social and architectural history point of $v_{i e w}{ }^{20}$ ) these spaces and their interdependent socio-spatial relations are in danger of being lost as the pressure of contemporary housing economics and development press in upon this previously derided and forgotten community (Mann 
2003, 119-120). The macro-economics of the UK's neoliberal development and local housing market speculation now appear to have risen to such extremes (Pallister 2015; Jones, Murie, and Piccard 2006) that house-hunters are willing to bypass and forget the engrained cultural misconceptions of Studd Hill in exchange for profitable housing speculation. The size and location of these humble plotland houses make them increasingly ripe for (re)development and can attract prices that (like many other situations in the UK - Selsey for example) stand in utter contempt and ignorance of the humble and impoverished beginnings of the original plotlanders, and their anarchistic aspirations for simple homes and lives. ${ }^{21}$

However, unlike the gentrification or demolition suffered by plotland sites like Selsey, Studd Hill's long-held isolation means many of the homes remain expressions of the reality of simple everyday lives. They reflect an architecture that is not dominated by a perception of housing as merely a commodity in a Westernised 'bricks and mortar' economy (Jones, White, and Dunse 2012, 17-18). Informal housing, be it in Studd Hill or examples drawn from the Global South, is defined by a far stronger connection with use value of housing for both individual people and their local community (J. F. C. Turner 1968). As such, the history and surviving legacy of plotlander housing sites like Studd Hill offer a critical counter-narrative to the presumptions and cultural perceptions of Westernised housing as economic investments and assets, rather than engaging with their inherent wider social relationships and potential benefits. In the context of wider national and global housing issues, can this critical opportunity to re-visit surviving plotlander community afford the possibility to propose a new informal housing revolution in the UK?

\section{Studd Hill: Successful informal housing}

The original essence of the plotlander architecture still largely dominates the feel of an island of informality and difference. At first it is difficult to recognise the original chalet houses beneath the rich variety of adaptations, extensions, and overcladding on show across homes that reflect a full spectrum from conventional to quirky, boring to whimsical, dilapidated to spectacularly charming. Digging a little deeper and looking past the surface adaptations of houses there remains a rich architectural plotlander narrative at Studd Hill. In the context of photos and plans of the original promotional 
leaflets used to sell the plots and chalet buildings it is far easier to observe the original skeletons at the core of houses that have since evolved into unique and fascinating homes. Several very basic core chalet forms and layouts appears to have inspired an extraordinary number of adaptation and extension solutions, and this in itself is a form of social production of space that is largely removed from contemporary conventional housing developments. Very few houses at Studd Hill look or feel the same, and it is this variety of adaptation itself that contrasts so abruptly against conventional housing development models that predominate contemporary housing in Herne Bay, and the collective wider everyday architectural landscape of Westernised space. ${ }^{22}$

Many of the innovative socio-spatial relations and solutions required to make Studd Hill work are impossible to imagine being accepted within the outside world of formal and conventional housing developments. Opportunities to adapt, extend, alter, and personalise our homes are an increasingly foreign idea in contemporary Westernised space. The ability to do so is seemingly strategically designed out of conventional housing, affected by both the social formalisation architecture and planning (Till and Schneider 2005), and our collective cultural acceptance of housing as economic asset (Paris 2009, 295-296) or object of consumption (Gram-Hanssen and Bech-Danielsen $2004,8)$ rather than a home. Whilst opportunities for contemporary housing adaptation still remain - UPVC conservatories, loft extensions, gardens, DIY decorating personalisations - these gestures can themselves be seen to conform to formal logic of the economic value of housing, rather than social need.

The slow intergenerational and piecemeal investments made in the humble and modest homes at Studd Hill exemplifies an explicit counter-narrative to prevailing comparison to the social values and relations that resonate from contemporary housing in the UK and wider Global North. Yet the conventional neoliberal cooption of housing as a social process into a process of commodification does not reflect the dynamic innovation of informal housing such as that at Studd Hill, or found across cities of the Global South (Wakely and Riley 2011; Joshi and Khan 2014). As John Turner famously observed, whilst Westernised development and housing is conventionally perceived as a noun, an object, and an economic asset (J. F. C. Turner 1972), at its core housing is a verb and a social process of production and reproduction (Bower 2015). 
Nowhere is the difference between formal and informal development more apparent than in the contrasts between the original plotlander homes at Studd Hill and the recently completed new housing development that has sprung up within the heart of the island. Built upon leftover farmland that had later become a small caravan park, the 14 new houses reflect a startlingly blunt rejection of the architecture and history of Studd Hill. In fact, it is evident from the complete lack of any historical analysis in the planning documentation for the project that neither the developers or planners made any conscious engagement with the historically informal nature of the area or the richness of its contemporary architectural language.

In contrast it would appear that quite the opposite is true. It is clear that a tacit desire to forcefully insert formal space within Studd Hill has been a key goal of the project from inception. The imposition of formality upon informal space is culturally required in order to validate economic speculation, and the reduction of social value into money and inequality (Bourdieu 2010, 156-162). The architectural language, spatial compositions, and even cultural tropes that define these new houses mark a profound rejection of the informality of the communities plotlander origins. At its simplest this is evident in the overall scale and density of the new houses, coupled with the repetition of only 2 basic house-types which leads to a complete lack of architectural (and even social or cultural) richness and variety.

Yet there are also subtler distinctions here that are more socially complicit than the overall architectural outcome. Boundaries conditions are solid (full height fences are found almost nowhere else in the area), as necessitated by an increased density required to maximize the opportunistic economic principles of speculative development. Houses are standardised, pacified, and bereft of opportunities for adaptation or the application of individuality. And crucially, as is expected with all new housing developments these new properties are all supplied with fully modern roads and pavements that abruptly end where they meet the existing un-adopted roads. ${ }^{23}$ This abrupt formalisation within the overall site exists as an alien island of convention within the local makeshift landscape (Hardy and Ward 1984, 8-12).

Whilst these new houses reflect remarkably self-referential design process, in the context of conventional contemporary housing in the UK they are not a necessarily 
'bad' examples of architecture. And this reveals the economic speculation at the heart of this formal interjection within Studd Hill: the new houses are 'architectural' enough so as to command market prices that bely the informal and unconventional nature of the original plotland context. Conventionality and cultural acceptance, what we might describe as cultural and spatial hegemony (Mouffe 2013b; Schmuely 2008), is economically intrinsic to speculative development viability.

Whilst it appears this new housing development at Studd Hill required a lengthy struggle to gain permission - with the development being fought over for a number of years and design iterations before finally being approved - the history and social landscape of the informal housing at Studd Hill has (unconsciously, ignorantly, perhaps purposefully?) been absent from all of the planning, development, or architectural debate surrounding this development. Thus, whilst a variety of financial contributions to the local council were garnered as part of now conventionally accepted planning approval negotiations none of this money has been earmarked to serve the existing Studd Hill community. Perhaps more unbelievably, nor has any financial compensation been levied to rebuild the community owned roads that the new houses occupants must drive over to reach their new tarmac island. ${ }^{24}$

This new housing development is the most striking change to affect Studd Hill in decades. Yet a wider redevelopment of Studd Hill continues apace today, albeit in a slower more piecemeal fashion. The architectural richness and variety of Studd Hill is at risk as there remains no local or national engagement with informal housing and plotlander sites as being of historically significant value. They represent an aspect of our architectural history that is effectively already forgotten or lost, along with an alternative way of life and the unique and valuable socio-spatial relations that such informal productions of space produced. And beyond this historical loss, today outside of Ward's documentations of the history of the plotlander movement the ideas of anarchist freedom and concordant Marxist social production of space that are embodied in places like Studd Hill remain removed from academic or political discussions of the inescapable damage produced by neoliberal housing in the UK. Ward's great advocacy remains unheard: "When We Build Again: Let's have housing that works!” (C. Ward 1985). 
If we believed that all plotlander housing was lost, forgotten, or gentrified into insignificance we were wrong. The informal and anarchist housing principles that define Studd Hill still exist today. And this itself would seem to prove that informal housing can survive and flourish in the UK, but it does so only when its cultural isolation becomes a shield against conventional housing speculation. Yet if like at Studd Hill there are lost examples of Colin Ward's beloved plotlander housing that have indeed survived and achieved the full potential of their humble anarchist origins then can we not learn from these examples as positive realisations of the potential of informal space in the UK to produce socially sustainable relationships and housing. And might we begin to question why can we cannot realise an informal housing revolution in the UK today.

\section{UK Informal Housing Today}

"[Whilst] the specific circumstances of the plotlands' evolution are now a matter of historical curiosity, the underlying dynamics of individual liberty, community and capital which are strongly imprinted in English society suggest a continued relevance for the lessons of the plotlands." (Mann 2003, 120)

As Ward observed in the 1970s and 80s, and Mann reiterated in 2003, there remains an inherently positive potential to learn from the anarchistic principles and informal social processes inspired the plotlander housing movement. However, one of the problems of both these respective analyses was the focus upon examples that had been lost, coopted, or formalised by gentrification. Yet Studd Hill proves that it is possible to find lost plotlander communities that have survived, and indeed in many social and spatial ways flourished, almost in spite of decades of neoliberal housing economics. Thus, rather than being merely a historical curiosity, examples like Studd Hill represent an opportunity to propose the possibility of new alternative and informal housing in the UK today.

Yet as interesting as the history of Studd Hill is, it is important to recognise that mere retrospection or fetishisation (Hatherley 2014) of plotander housing offers little opportunity to provoke positive discussion and change in connection with the reality of 
the contemporary (perpetual?) housing 'crisis' that the UK faces. ${ }^{25}$ The interconnection of factors affecting housing and social space in the Westernised world has become so complicated as to make any concise or incisive critical analysis seemingly impossible without becoming politically abstract or ideologically subjective. However as with wider socio-political trends in Western society (Massey 2011; Bauman 2000), it is clear is that Westernised space continues to be ideologically driven towards a singular neoliberal vision of conventional housing and formally planned development (Brenner 2014).

This form of speculative and commercially driven development continues to emerge en mass without any sustained critical engagement by the architectural press or RIBA. It is a model that values exchange value over use value (Lefebvre 1969, 67; Lefebvre 1991, 356), formalisation over choice, convention over individuality, control over freedom (Fichter and Turner 1972; Franks 1999), and ultimately financial speculation over people (Brenner and Theodore 2002, 353-356). And more worryingly, it is an ideological narrative that is so deeply inculcated in the social consciousness of Westernised space as to be seemingly impossible to unpick and unravel (Harvey 2015a).

Though it often goes unmentioned in Western discourse, informal building construction (and increasingly economies) already predominates the formal production of space as a global condition (Neuwirth 2006; Dawson and Hayes Edwards 2004; Parnell and Oldfield 2014; Miraftab, Wilson, and Salo 2015). The balance of global power may well be shifting away from traditional nationalist points of agglomeration defined by the historically colonial Western powers (Massey 1999; Brenner 1997). The growth of the post-colonial Global South appears to be shattering the illusion of Western projections of development and social equality being interconnected. Instead it is increasingly clear that global neoliberal development is proliferating and exaggerating the production of inequality that underpins and drives the global neoliberal and capitalist economic structure (Goonewardena et al. 2008).

It is unlikely that the story of Studd Hill offers a singular key with which to challenge the assumed logical cohesion of formal housing conventions in the UK, let alone the wider global questions of informal space facing the world. Yet as an example of the 
positive potential of informal development in a Western context it remains potentially invaluable. It offers an opportunity to critically reconsider and learn from the spatial relationships and conditions that gave rise to the positive informality of plotlander sites, and to confront some challenging socio-spatial questions: is there a cultural empathy for alternative forms of housing? If not, (how) can we seek to agonistically (Mouffe 2013a) produce one? What are the political and economic challenges/implications of an informal housing economy? And how might we engage with space and architecture differently in order to facilitate new models of alternative housing in the UK?

The economic speculation and commodification of formal and conventional housing development in the UK has become so pervasive that almost no opportunity exists for citizens to engage with alternative architectural or housing development (Alistair Parvin et al. 2011; Alastair Parvin 2015; Alastair Parvin 2013). It should be recognised that in wider Europe this is not universally the case. In the Netherlands housing development experiments over the past two decades have led to numerous projects that have confronted the positive potential of user-driven housing, such as that in Amsterdam and Almere (Metz 2010). In Germany and Scandinavia there are a growing number of housing projects driven by communities and social collectives who are effectively replacing the developers and becoming the masters of their own fates (McCamant and Durrett 2011; Sustainability 2012). By reinvesting the money that would usually become a developer's profit margin into better design and sustainability they are beginning to deliver superior architecture through engaging as a community in the social production of their own space.

In the UK we can begin recognise architectural practices that are engaged with alternative housing strategies, notably Architecture 00 in London. Their work is founded upon a broad and multifaceted engagement with alternative models and approaches to architectural practice, seeking to provoke or empower social change (Architecture 00 2011). In addition to producing award winning building projects, Architecture 00 are known for being key founders of the 'wikihouse' open-source building design. This innovative project seeks to inspire a potential 'third industrial revolution' by engaging with the creative commons and open source social processes that have emerged from the origins of the collective freedom potential of the internet (Alastair Parvin 2013). 
The relative (if small and isolated) successes of the wikihouse project is indeed an inspiration for those seeking alternative conceptions of architectural practice and social agency in a Westernised context. Notably the wider implications of such open-source approaches to house building - adaptability, user-defined, economic building - reflects many of the social questions and problems that drove the plotlander movement, but recontextualised against the challenges and opportunities of the twenty-first century. However, the project faces substantial challenges that go beyond the practicable viability of the architecture itself. The economic, political, and social confrontation offered by a user-defined building system strikes at the fundamental socio-cultural hegemonies of formalised Western space and life. This cultural hegemony is seemingly perhaps far more difficult to overcome than the already substantial achievement of designing houses you can print and build yourself.

These examples of alternative housing development in the UK and across Europe each only offer aspects of the positive potential found in plotlander sites and the social relations of space that produce these informal landscapes. The strategic immovability of contemporary formal planning systems that make any (sudo-) anarchist, informal, or plotlander emergence seemingly impossible. Yet if we take a moment to briefly study the core issues that prevent a new informal landscape from emerging we recognise both how potentially simple and overwhelmingly positive such social shifts might be. It is increasingly clear that the real challenge is to affect the political impotence of architecture to affect planning questions so wholly governed by the economic need to maintain inexorable growth, commodification, and the acceptance of housing as merely another commodity of consumption.

A primary issue to consider is the historically marginal land from which plotlander sites emerged do not exist in contemporary Westernised space. The historic socio-economic conditions that led to the emergence of informal housing are a distant and long forgotten memory in the UK. Marginal farming land with implausibly low economic value no longer exist, and if and where they still do, they are now subject to planning laws that (perhaps rightly) 'protect' the British countryside. The peripheral and left-over sites that were the basis of the organic emergence of plotlander sites now exist only in the Global South where informal land ownership and planning policies are themselves expressions of the necessity of informality to solve real-world problems. 
These economic and spatial conditions are almost impossible to consider in a contemporary UK context, where almost every marginal shred of land that can be built on has already been purchased. ${ }^{26}$ This issue of planning legislation is almost certainly the key issue that underpins the implausible economic value of land in the UK. Since the advent of the 1947 Town and Country Planning Act that so successfully stopped the emergence of further informal plotlander housing developments. Land deemed plausible for building on by the planning authority is largely swallowed up by commercial developers who can afford to play the politically accepted game of land speculation in order to manipulate the economic landscape that has come to define planning negotiations and section 105 agreements.

The potential answers to the interconnected questions of land value, housing speculation, and formalised planning are unequivocally provocative. Alistair Parvin has recently cited the need to introduce a $\mathrm{C} 5$ class of land ${ }^{27}$, generating two parallel land markets; one for conventional speculative market housing, and a new separate market for people to just want to buy land \& build a place to live / work. This kind of change to the planning system would in essence be seeking to create space and opportunity for a new informal or alternative housing revolution. Here projects like wikihouse have the potential to open up new possibilities for architectural innovation, building cheaper and more innovative homes and communities without the need to fulfill conventional criteria of economic speculation. In essence, an informal C5 planning and land market would create the chance to produce future informal housing communities like Studd Hill, and thus the potential to reimagine housing as a long-term social investment in place; building produce lives and (economically/socially) subsistent spaces.

This shift in planning would provide a fundamental freedom for individuals and communities to house themselves in ways that reflect the same social relations of innovation and freedom found in the Global South. The cost of this shift is difficult to qualify. Unlike the wild-west construction imposed by the historical and cultural context of the plotlander movement, relinquishing control of housing to an informal market does not necessitate lower quality buildings. In fact, the combined effects of users defining the standards for their own homes, and the lack of imposed profit margins allows from development speculation presents the opportunity for actual increased construction standards. It does pose the possibility of having to confront the 
tastes of other people expressed in built form, though as Studd Hill shows this is likely to lead to a bricolage effect of richness and variety that is compelling in contrast to formalised and standardised cookie-cutter housing.

The major impact would be felt by private housing development companies who would no longer hold the housing market to ransom. In all likelihood they would continue to control a large proportion of the housing market whilst people learn to understand the opportunities of informal and user-defined housing. Yet the inevitable challenge to developer housing conventions does not necessitate their destruction, merely the need for them to adapt to a new market. Small, more locally engaged housing companies will inevitably form to serve the needs of C5 self-builders - not everyone will build their home from scratch by themselves, and builders can still make money out of low-cost construction if they are helped, supported, and willing to engage with a changing world instead of grasping at the inequity of the current system.

There would also be a substantial long-term impact upon the existing inflated values of existing UK housing stock - which remains perhaps the most likely reason such alternative housing will emerge in the UK. Yet the opportunity this presents to regional housing economies is potentially substantial. The introduction of C5 land that cannot be used to make speculative profit affords communities the opportunity to develop land previously deemed unviable. Brown-field sites can easily accommodate community and informal housing models, and whilst the protection of the green-belt is fundamentally linked to limiting the damage afflicted on 'natural' countryside, C5 housing that sought to engage with and improve rural communities could access greenbelt sites at low costs because the lack of speculative profit in each development would limit the land value to socially balanced levels.

It would also be prescient to note that due to the economic model of subsistence not profit that defines such a development model this shift in planning policy and housing development would not be targeted at a working-class market. It would not be a state based housing solution driven purely by socialist politics. As predicted by anarchist critiques of state socialism, centralised interventions in housing models are themselves inherently prone to boom-and-bust cycles of deprivation and political incompetence/manipulation (Hatherley 2011). 
Instead, the agonistic incitement of a grass-roots social recognition of the futility of convectional housing market economics and concurrent cultural lifestyle would be free of class politics. Surely it would most likely appeal most directly to the disenfranchised urban working-class poor, but the opportunity should not be manipulated to become a new variation based upon state sanctioned social housing criteria, 'key-worker' projects. Ward's arcadia for all is just that: a future freely available for all by merely relinquishing the concept of housing as a keystone of cultural dependency on economic gain as the primary aim in life.

This would be the most fundamental shift in planning, housing, and economic policy in the UK and Western space in centuries. Yet it is not without precedent. The various enclosures from 1773 to 1882 in the UK seized control of common 'waste' land from subsistence peasant farmers. The subsequent urban migration of rural populations, coinciding with the industrial revolution of the $19^{\text {th }}$ century, led to the introduction of the allotments acts as a means to provide space for subsistence farming in towns and citeis. Given the axiomatic implausibility of the current UK housing market being resolved by neoliberal market economics $\mathrm{C} 5$ planning legislation would in essence be the introduction of a subsistence housing market as a means to challenge the economic and social stranglehold housing places upon citizens in the UK. We would no longer need to spend put whole lives working to support a mortgage and retirement. 'When we build again' we could truly find 'an architecture that works' (J. F. C. Turner 1968) and 'housing that works' (C. Ward 1985). We could have twenty-first century 'arcadia for all'. 


\section{Endnotes}

${ }^{1}$ This is not to suggest that informal housing is not far more widespread than merely the South-East, but to clearly demarcate the field of study in this essay as limited to these specific plotlander sites. Future research on wider informal housing models is necessary and vital in order to widen the discussion of these alternative housing and development models in the UK.

${ }^{2}$ The notion of informal housing is perhaps most conventionally identified with favelas, barrios, and slums as the most culturally recognisable examples of informally produced settlements. It inherently by definition describes a variety of urban conditions that exist outside of the conventions of formal planning, yet the spectrum of informality and difference to formal planning models is far more complex than the structuralist, prescriptive, and negative binary of the terms formal and informal suggests.

${ }^{3}$ This paper uses the conventionally accepted terms of Global South and Global North to distinguish between the developed first- and second-world economies predominantly found in the North, and the context of the developing third-world in the South. The loose geographical nature of the Global South North terms is perhaps as equally loaded with political inaccuracy and tension, however since the end of the Cold War it has become widely recognised as the most acceptable terminology when discussing global development (Reuveny 2009). Whilst this distinction is recognised as an overly simplistic socioeconomic and political divide, due to the inherently negative implications of the alternative terms developed and developing, or first- and third-world economies, North and South have become the most conventionally accepted distinction used in global academic discourse.

The Global North loosely consists of the United States, Canada, Europe and East Asia, whilst the Global South consists of Africa, Latin America and developing Asia, South America and the Middle East. The North is generally understood to be formed of richer economies, but also is distinguished by the prevalence of adequate social conditions food and shelter, and education for populations. The inverse is observed in the Global South, where three-quarters of the worlds population control only one-fifth of the worlds income, and only $10 \%$ of the manufacturing industries are both owned and controlled by the South (Therien 1999).

However, the use of the terms Global North and South is increasingly understood through a more progressive academic articulation of the challenges of global capitalism. This articulation would seek to intersect with the discourse of both Mouffe and Massey who interpret the hegemonic characteristics of space being disseminated from nodal points at the heart of geometries of power (Massey 2004, 12; Mouffe 2013b, 29). Here it is thus equally important to recognise distinctions between centre and periphery, majority and minority, formal and informal, within the contexts of individual countries, regions and cities (Ferguson and Gupta 1992, 19). In this articulation it is recognised that elements of the socio-economic and political inequality faced by the Global South are recognised within the borders of the Global North territories.

${ }^{4}$ For more on culturally negative conceptions of otherness see: (Fabian 2002; Moore-Gilbert 2000; Spivak 1985; Said 2003)

${ }^{5}$ Moralists such as William Morris or Richard Jefferies were crucial in exploring such ideas of freedom and nature as counters to urbanisation (Morris 2009; Faulkner 1995; Jefferies 2008), and these conditions for urban exodus increased exponentially in the aftermath of the bombing of London in the Second World-War.

${ }^{6}$ The historical logic and cultural questions of this urban/rural paradox are not apart of this study, but they do offer the tantalising beginnings of a critique on the inevitability of contemporary urbanisation trends globally and locally. For more on this paradox we might begin to engage with discussions of urban/rural dialectics in the work of Henri Lefebvre (Elden and Morton 2015).

${ }^{7}$ What today is culturally understood as NIMBY'ism (Not In My Back Yard).

${ }^{8}$ Herne Bay's claim to fame is its Victorian pier which was the second longest in England at an impressive 1,154 $\mathrm{m}$ in 1899 (its third iteration). The pier connected Herne Bay to London via the steamer ships that travelled the Thames Estuary to allow city dwellers to become early tourists and escape to the seaside. The original pier burnt down in an apparent construction accident in 1970. A new pavilion opened in 1976 defining a remarkably shorter pier until in 2012 it was closed and demolished due to lack of funding. The end of the original pier still exists as a landmark in the sea that still seems to hint at the lost historic grandeur of the town.

${ }^{9}$ Not that this stopped Margate trying with its controversial and long ill-fated Turner gallery. Whilst the end product by Chipperfield Architects offers a useful opportunity for architectural photographs, the long 
term benefits of this building and its contribution to the social sustainability of a working class town with significant economic challenges is very uncertain. Perhaps more interesting is the attempted revival of the Dreamland amusement park at Margate which still appears to potentially appeal to a working class cultural identity - albeit now with a façade of kitsch sentimentalism.

${ }^{10}$ Here an open ended, confrontational, and largely rhetorical question is left hanging outside of the remit of this essay: what would the plan for working class regeneration town look like? Has there ever been a successful working class regeneration? And is this agenda even a part of the social and political context of contemporary Western culture?

${ }^{11}$ The affect of the economic power and inequality created by the London property market across the South of England is remarkable, and ultimately, must be unsustainable. Yet the dangerous socioeconomic conditions that drive this inexorable housing market trajectory are so deeply rooted at the foundations of our economy that to suggest the need for house prices to fall, or for a different system altogether (more on this later) seems almost heretical.

${ }^{12}$ Notably the local identity issues of the pothole riven un-adopted roads that remain a legal grey area, but more importantly, the increasingly forgotten social stigmatism of being informal and different.

${ }^{13}$ It is noticeable on a contemporary map of Studd Hill that roads seem to end abruptly at the coastline where previously they would have formed a classic plotlander grid layout. Anecdotal evidence from interviews with the members of the Studd Hill Residents Association suggest that a number of homes were lost to land erosion prior to the completion of the sea defense wall.

${ }^{14}$ Mr Frank Stedman was a notorious serial plotland developer (Hardy and Ward 1984, 138-142) who is known to have developed over a dozen plotland sites, many of which are now lost and forgotten. He was also the originator of the more (in)famous Jaywick plotland site near Clacton on Sea in Essex. This almost identically marginal site, situated almost directly North of Studd Hill, is well known as an example of the potentially disastrous outcome of an isolated plotlander site. Jaywick today is decidedly less resilient and actively buoyant for reasons that must remain, at this time, merely speculative. However, it likely that when compared to Studd Hill key factors include the travel distance, and lack of transport infrastructure, as well as the sad deaths of 35 residents of Jaywick in the 1953 great flood, whereas in Studd Hill there were none. These factors, along with an apparent lack of local employment opportunities and social fallout in Essex appear to have led to the isolation and slow breakdown of the social values and community cohesion at Jaywick. Today whereas Studd Hill is largely prospering with property values at worryingly high levels it is stunning to note that you can currently buy a plot (with accompanying original and undeveloped chalet) in Jaywick for $£ 25,000$.

15 Details taken from the original sales pamphlet materials owned by the Studd Hill Residents Association.

${ }^{16}$ The residents themselves paid for these services after Stedman imposed and collected a levy from all the properties. This method of local organisation and service provision stands at odds with formal development models and can perhaps be linked to some of the ongoing problems at Studd Hill.

${ }^{17}$ In the case of Studd Hill the 1947 seems to have had more severe implications than the precedeing 1932 Town and Country Plannig Act, though Ward and Hardy describe the relative impacts of both as crucial to the decline of housing informalityin the UK (1984, 40-47, 49-51).

${ }^{18}$ It certainly offers an architectural richness which many socially engaged architects would yearn to work with.

${ }^{19}$ I can somewhat confidently express these broad claims as my family have roots in Herne Bay going back over 30 years. Discussion with family, local friends, and neighbours, etc reveal a common thread of mistrust which always returns to a culturally engrained (yet somehow uncritical and almost unconscious) bias against Studd Hill.

${ }^{20}$ Though recent improvements must be recognised as offering much needed improvements to residents whose original homes were (again much like contemporary informal housing in the Global South) of a very low standard when compared to contemporary Western living standard expectations.

${ }^{21}$ Whether this absorption of plotland sites within the conventional housing market should be considered a positive or negative progression is distinctly ambiguous subject for debate, and there is little to no academic debate on the intergenerational growth and development of historically informal housing in the UK outside of Ward's discourse. It does however reflect the amazing qualities of capitalism to coopt and absorb alterity. It also suggests the opportunity (necessity?) to seek to actively counter this trait of capitalisms affects on the housing industry. The need for political and planning legislation to counter these affects reflect much the same political shift inspired 'The Allotments Acts' that was passed in order to counter the social damage caused by various Land Enclosure Acts and the rapid urbanisation of Victorian industrial Britain. What such a political shift would look like is a research subject that will be pursued in a larger upcoming related project. 
${ }^{22}$ i.e not featuring in architectural journals.

${ }^{23}$ These new roads have not been adopted by the council but are to be maintained by a development management company that will maintain the site as per conventional modern housing developments.

${ }^{24}$ This despite 7 fantastically intriguing yet unnamed appendix documents within the planning documentation that extensively (60 photos of potholed roads) documents the poor state and patchwork nature of the un-adopted roads that surround the new island development, yet offer no discussion of an ongoing plan to engage with the problem. Evidence of this commitment to repave the roads as part of the development is once again anecdotal, but this in itself is highly suggestive of the lack of planning support given to the local community even when issues that directly affect its residents are being decided by political agencies without care or thought for issues facing residents of informal spaces.

${ }^{25}$ It seems reasonable to challenge the futility of abstract historicism in the context of the extensive career and academic study of Colin Ward remaining a little studied and much undervalued niche of architectural discourse.

${ }^{26}$ This stands in notable contrast to the situation in the Netherlands where new marginal land is created by damming and moving water and land to provide new islands and lagoons to build upon, whether it be by conventional developers or by self-builders on building plots provisioned with basic services and assurances of long-term support from local political agencies.

${ }^{26}$ This proposal by Parvin was discussed in a Twitter conversation conducted informally in 2015.

\section{Figure captions}

Fig 1: Reproduction of Colin Ward's original mapping analysis of plotlander settlements in the UK.

Fig 2: Train carriages converted into seaside plotlander home at Selsey. Hidden amongst the increasingly formalised housing on the coastline, finding the original plotlander homes become a treasure hunt for an almost mythical architectural unicorn.

Fig 3: Beautiful holiday experiences at upper middle class prices. The commodification of an informal style produced out of necessity and economic absence.

Fig 4: Studd Hill circa 1870

Fig 5: Studd Hill circa 1970

Fig 6: Studd Hill today: Informal un-adopted roads.

Fig 7: Studd Hill today: 'Shabby-chic' housing?

Fig 8: Studd Hill today: Adaption and variety: simple, humble, and informal.

Fig 9: Studd Hill today: Homes valued by social function rather than economic value. 
Fig 10: Studd Hill today: Recently built housing rejects informal context and conforms to contemporary housing perception of formality, acceptability, and socio-economic value.

\section{References}

Aravena, Alejandro, and Andres Lacobelli. 2012. Alejandro Aravena: Elemental: Incremental Housing and Participatory Design Manual. Ostfildern, Germany: Hatje Cantz.

Architecture 00. 2011. 'Compendium For The Civic Economy: What the Big Society Should Learn from 25 Trailblazers'. 00 Publications.

Bakunin, Mikhail. 1872. 'Letter to the Intertionalists of the Romagna'.

Bauman, Zygmunt. 2000. Globalization: The Human Consequences. New York: Columbia University Press.

Benello, George. 1967. 'Wasteland Culture'. Our Generation 5 (2): 19-47.

Bianchini, Franco. 1994. Cultural Policy and Urban Regeneration: The West European Experience. Edited by Michael Parkinson. New edition edition. Manchester: Manchester University Press.

Bourdieu, Pierre. 2010. Distinction: A Social Critique of the Judgement of Taste. London: Routledge.

Bower, Richard. 2015. 'Dialectical Materialism and the Alternative Architecture of John F.C. Turner'. In Changing Principles and Praxis in Urban Research, edited by Quazi Zaman and Igea Troiani. Cambridge: Cambridge Scholars.

- 2016. Difference, Multiplicity, Otherness: Space and Architecture Reimagined. London: Routledge.

Brenner, Neil. 1997. 'Global, Fragmented, Hierarchical: Henri Lefebvre's Geographies of Globalisation'. Public Culture 10 (1): 135-67.

- 2014. Implosions/Explosions: Towards a Study of Planetary Urbanization. JOVIS Verlag.

Brenner, Neil, and Nik Theodore. 2002. 'Cities and the Geographies of "Actually Existing Neoliberalism”. Antipode 34 (3): 349-79.

Burgess, Rod. 1977. 'Petty Commodity Housing or Dweller Control? A Critique of John Turner's Views on Housing Policy.' World Development 6: 1105-33. . 1978. 'Petty Commodity Housing or Dweller Control'. World Development 6 (9/10): 1105-33. 
. 1982. 'Self-Help Housing Advocacy: A Curious Form of Radicalism. A Critique of the Work of John F.C. Turner.' In Self-Help Housing: A Critique, edited by Peter M Ward. London: Mansell.

Charnock, Greig. 2010. 'Challenging New State Spatialities: The Open Marxism of Henri Lefebvre'. Antipode 42 (5): 1279-1303.

Davis, Mike. 2007. Planet of Slums. Reprint. London: Verso.

Dawson, Ashley, and Brent Hayes Edwards. 2004. 'Introduction: Global Cities of the South'. Social Text 22 (4): 1-7.

DeMoss-Norman, Tiwanna. 2015. 'From Informal Settlements to Formality: A Resettlement Group's Adaptation to a Newly Planned Community in Port Elizabeth, South Africa'. Economic Anthropology 2 (1): 224-40. doi:10.1002/sea2.12026.

Elden, Stuart, and Adam David Morton. 2015. 'Thinking Past Henri Lefebvre: Introducing "The Theory of Ground Rent and Rural Sociology": Thinking Past Henri Lefebvre'. Antipode, July, n/a - n/a. doi:10.1111/anti.12171.

Fabian, Johannes. 2002. Time and the Other. New York: Columbia University Press.

Fathy, Hassan. 1976. Architecture for the Poor: An Experiment in Rural Egypt. Chicago: University of Chicago Press.

Faulkner, Peter. 1995. William Morris the Critical Heritage. London: Routledge.

Ferguson, James, and Akhil Gupta. 1992. "Beyond "Culture": Space, Identity and the Politics of Difference'. Cultural Anthropology. American Anthropological Association 7 (1): pp 6-23.

Fernández-Maldonado, Ana María. 2007. 'Fifty Years of Barriadas in Lima: Revisiting Turner and De Soto'.

Fichter, Robert, and John FC Turner, eds. 1972. Freedom to Build. New York: The Macmillan Company.

Franks, Ben. 1999. 'New Right / New Left: An Alternative Experiment in Freedom'. In Non-Plan: Essays on Freedom, Participation and Change in Modern Architecture and Urbanism, edited by Jonathan Hughes and Simon Sadler. London: Architectural Press: Routledge.

Glynn, Sean, and John Oxborrow. 1976. Interwar Britain: A Social and Economic History. London: Allen \& Unwin.

Goonewardena, Kanisha, Stefan Kipfer, Richard Milgrom, and Christian Schmid. 2008. 'Globalizing Lefebvre?' In Space, Difference, Everyday Life: Reading Henri Lefebvre. New York: Routledge. 
Graham, Robert, ed. 2005. Anarchism: A Documentary History of Libertarian Ideas. Montreal ; New York: Black Rose Books.

Gram-Hanssen, Kirsten, and Claus Bech-Danielsen. 2004. 'House, Home and Identity from a Consumption Perspective'. Housing, Theory and Society 21 (1): 17-26. doi:10.1080/14036090410025816.

Habraken, John. 1972. Supports: Alternative to Mass Housing. London: Architectural Press.

Hardy, Dennis, and Colin Ward. 1984. Arcadia For All: The Legacy of a Makeshift Landscape. London: Mansell.

Harris, Richard. 1999. 'Slipping Through the Cracks: The Origin of Aided Self-Help Housing 1918-1953'. Housing Studies 14 (3): 281-309.

Harvey, David. 2012. Rebel Cities. London: Verso.

- 2015a. Seventeen Contradictions and the End of Capitalism.

—. 2015b. 'Listen, Anarchist!” A Personal Response to Simon Springer's "Why a Radical Geography Must Be Anarchist'. DavidHarvey.org.

Hatherley, Owen. 2011. A Guide to the New Ruins of Great Britain. Reprint edition. London: Verso Books.

- 2014. 'The Problems with Favela Chic'. Disegno 7. http://www.disegnodaily.com/article/the-problems-with-favela-chic.

Illich, Ivan. 1973. Tools for Conviviality. London: Calders and Boyars.

Jefferies, Richard. 2008. After London or Wild England. Champaign, Ill.: Book Jungle.

Jones, Colin, Alan Murie, and Bertrand Piccard. 2006. Right to Buy: Analysis and Evaluation of a Housing Policy. 1 edition. Oxford; Malden, MA: John Wiley \& Sons.

Jones, Colin, Michael White, and Neil Dunse, eds. 2012. Challenges of the Housing Economy: An International Perspective. 1 edition. Oxford; Ames, Iowa: WileyBlackwell.

Joshi, Sharadbala, and M. Sohail Khan. 2014. 'Housing Futures: Housing for the Poor in Sri Lanka'. In Affordable Housing in the Global South: Seeking Sustainable Solutions. New York: Routledge.

Kotanyi, A, and R Vaneigem. 1961. 'Elementary Program of the Bureau of Unitary Urbanism'. In Situationist International Anthology, edited by Ken Knabb, 6567. California: Berkeley.

Kropotkin, Peter. 2006. Mutual Aid: A Factor of Evolution. Dover Books on History, Political and Social Science. New York: Dover. 
Lefebvre, Henri. 1969. The Explosion. Translated by Alfred Ehrenfeld. New York: Monthly Review Press.

. 1991. The Production of Space. Translated by Donald Nicholson-Smith. Oxford: Blackwell Publishing.

Lummis, C. Douglas. 2010. 'Equality'. In The Development Dictionary, 38-54. London: Zed Books.

Malpass, Peter. 2003. 'The Wobbly Pillar? Housing and the British Postwar Welfare State'. Journal of Social Policy 32 (4): 589-606. doi:10.1017/S0047279403007177.

Mann, William. 2003. 'The Plotlands Experience: The Self-Build Settlements of Southeast England'. Oase Journal, no. Spring: 110-23.

Massey, Doreen. 1999. 'Power-Geometries and the Politics of Space-Time'. In . University of Heidelberg: Heidelberg: Department of Geography.

2004. 'Geographies of Responsibility'. Geografiska Annaler: Series B, Human Geography 86 (1): 5-18.

- 2005. For Space. London: Sage Publications.

2006. 'Space, Time and Political Responsibility in the Midst of Global Inequality'. Erdkunde 60 (2): 89-95.

2011. 'A Counterhegemonic Relationality of Place'. In Mobile Urbanism: Cities and Policymaking in the Global Age, edited by Eugene McCann and Kevin Ward. Globalization \& Community Series. Minneapolis: University of Minnesota Press.

Matos, Mar, J. 1984. 'Desborde Popular Y Crisis Del Estado (Popular Overflow and Crisis of the State)'. Lima, IEP.

McCamant, and Durrett. 2011. Creating Cohousing. Gabriola Island, B.C: New Society Publishers.

McGuirk, Justin. 2014. Radical Cities: Across Latin America in Search of a New Architecture. London; New York: Verso.

- 2015. 'Urban Commons Have Radical Potential - It's Not Just about Community Gardens'. The Guardian, June 15, sec. World Cities. http://www.theguardian.com/cities/2015/jun/15/urban-common-radicalcommunity-gardens.

Merrifield, Andy. 2014. The New Urban Question. Pluto Press.

Metz, Tracy. 2010. 'New Town in the Polder'. American Planning Association, December, 34-38. 
Miraftab, Faranak, David Wilson, and Ken Salo, eds. 2015. Cities and Inequalities in a Global and Neoliberal World. Abingdon, Oxon; New York, NY: Routledge.

Moore-Gilbert, Bart. 2000. 'Spivak and Bhabha'. In A Companion to Postcolonial Studies A Companion to Postcolonial Studies, edited by Sangeeta Ray and Henry Schwartz. Oxford: Blackwell Publishing.

Morris, William. 2009. News from Nowhere. Edited by David Leopold. Reissue edition. Oxford: OUP Oxford.

Mouffe, Chantal. 2013a. Agonistics: Thinking The World Politically. London: Verso. . 2013b. 'Space, Hegemony and Radical Critique'. In Spatial Politics: Essays for Doreen Massey. Chichester: Wiley-Blackwell.

Neuwirth, Robert. 2006. Shadow Cities: A Billion Squatters, A New Urban World. New Edition. New York: Routledge.

2012. Stealth of Nations: The Global Rise of the Informal Economy. Reprint. New York: Anchor Books.

Newnham, David. 2000. 'Shifting Sands'. The Guardian, August 12, sec. Life and style.

http://www.theguardian.com/lifeandstyle/2000/aug/12/weekend.davidnewnha $\mathrm{m}$.

Pallister, James. 2015. 'The Housing Crisis: How Did We Get Here?' Accessed August 14. http://www.architectsjournal.co.uk/news/the-housing-crisis-how-did-weget-here/8685212.article.

Paris, Chris. 2009. 'Re-positioning Second Homes within Housing Studies: Household Investment, Gentrification, Multiple Residence, Mobility and Hyperconsumption'. Housing, Theory and Society 26 (4): 292-310. doi:10.1080/14036090802300392.

Parnell, Susan, and Sophie Oldfield, eds. 2014. The Routledge Handbook on Cities of the Global South. New York: Routledge.

Parvin, Alastair. 2013. 'Architecture (And The Other 90\%): Open-Source Archteicture and the Design Commons'. Architectural Design 83 (6): 90-95.

. 2015. 'An Open Manifesto for Housing'. Medium. October 4. https://medium.com/@AlastairParvin/an-open-manifesto-for-housinga56cf4eed2a1.

Parvin, Alistair, David Saxby, Cristina Cerulli, and Schneider, Tatjana. 2011. 'A Right to Build'. University of Sheffield. http://issuu.com/alastairparvin/docs/2011_07_06_arighttobuild.

Paton, Kirsteen. 2014. Gentrification: A Working-Class Perspective. New edition edition. Farnham, Surrey, UK ; Burlington, VT: Ashgate. 
Reuveny, Rafael X. 2009. 'The North-South Divide and International Studies: A Symposium'. International Studies Review 9 (4): 556-64.

Rolnik, Raquel. 2013. 'Late Neoliberalism: The Financialization of Homeownership and Housing Rights: Debates and Developments'. International Journal of Urban and Regional Research 37 (3): 1058-66. doi:10.1111/1468-2427.12062.

Roy, Ananya. 2011. 'Slumdog Cities: Rethinking Subaltern Utopianism'. International Journal of Urban and Regional Research 35 (2): 223-38.

Rudolfsky, Bernard. 1987. Architecture Without Architects: A Short Introduction to Non-Pedigreed Architecture. Reprint. University of New Mexico Press.

Sachs, Wolfgang. 2010. The Development Dictionary. A Guide to Knowledge as Power. 2nd ed. London: Zed Books.

Said, Edward. 2003. Orientalism. London: Penguin classics.

Schmuely, Andrew. 2008. 'Totality, Hegemony, Difference: Henri Lefebvre and Raymond Williams'. In Space, Difference, Everyday Life: Reading Henri Lefebvre. New York: Routledge.

Sennett, Richard. 2004. Respect: The Formation of Character in an Age of Inequality. London: Penguin.

Shields, Rob. 1999. Lefebvre, Love \& Struggle; Spatial Dialectics. London: Routledge.

Spivak, Gayatri Chakravorty. 1985. 'Scattered Speculations on the Question of Value'. Diacritics, Marx after Derrida, 15 (4): 73-95.

Springer, S. 2014. 'Why a Radical Geography Must Be Anarchist'. Dialogues in Human Geography 4 (3): 249-70. doi:10.1177/2043820614540851.

Sustainability, Institute for Creative. 2012. CoHousing Cultures: Handbook for SelfOrganized, Community-Oriented and Sustainable Housing: Handbuch Für Selbstorganisiertes, Gemeinschaftliches Und Nachhaltiges Wohnen. Bilingual edition. Berlin: JOVIS Verlag.

Therien, Jean-Philippe. 1999. 'Beyond the North-South Divide: The Two Tales of World Poverty'. Third World Quarterly 20 (4): 723-42.

Till, Jeremy, and Tatjana Schneider. 2005. 'Flexible Housing: The Means to the End' 9: 287-96. doi:10.1017/S1359135505000345.

Turner, John F.C. 1968. 'The Squatter Settlement: Architecture That Works'. Architectural Design 38: 355-60. . 1972. 'Housing as a Verb'. In Freedom To Build. Basingstoke: Macmillan Education.

Turner, John FC. 1976. Housing by People: Towards Autonomy in Building Environments. London: Marion Boyars. 
. 1983. 'From Central Provider to Local Enablement'. Habitat International 7 (5/6): 207-10.

. 1986. 'Future Directions in Housing Policy'. Habitat International 10 (3): 725 .

Wakely, Patrick, and Elizabeth Riley. 2011. 'The Case of Incremental Housing'. Cities Alliance Policy Research and Working Papers Series.

Ward, Colin. 1985. When We Build Again: Let's Have Housing That Works! London: Pluto Press.

_. 1996a. Anarchy in Action. London: Freedom Press.

. 1996b. Social Policy: An Anarchist Response. New edition edition. London: Freedom Press.

- 1999. 'Anarchy and Architecture'. In Non-Plan: Essays on Freedom, Participation and Change in Modern Architecture and Urbanism, edited by Jonathan Hughes and Simon Sadler. Architectural Press: Routledge.

- 2004. Anarchism: A Very Short Introduction. Very Short Introductions 116. Oxford; New York: Oxford University Press.

Ward, Colin, and Dennis Hardy. 1972. 'Plotlanders'. Oral History Journal 13 (2): 5770 .

Ward, Peter M. 2008. 'Self-Help Housing Ideas and Practice in the Americas'. In Planning Ideas That Matter: Livability, Territoriality, Governance and Reflective Practice, edited by Bishwapriya Sanyal, Lawrence J. Vale, and Christina Rosan. Cambridge MA: MIT press. 